\title{
Continental smokers couple mantle degassing and distinctive microbiology within continents
}

\author{
Authors: Laura J. Crossey ${ }^{1}$, Karl E. Karlstrom ${ }^{1}$, Brandon Schmandt ${ }^{1}$, Ryan R. Crow ${ }^{1,5}$, Daniel \\ R. Colman ${ }^{2}$,Brandi Cron ${ }^{1}$, Cristina D. Takacs-Vesbach ${ }^{2}$, Clifford N. Dahm ${ }^{2}$, Diana E. Northup ${ }^{2}$, \\ David R. Hilton ${ }^{3}$, Jason W. Ricketts ${ }^{1}$, Anthony R. Lowry ${ }^{4}$
}

\begin{abstract}
Affiliations:
1. Department of Earth and Planetary Sciences, University of New Mexico, Albuquerque, New Mexico,87131,crossey@unm.edu (correspondingauthor),kek1@unm.edu, crow.ryan@gmail.com, jwricketts8@gmail.com

2. Department of Biology, University of New Mexico, Albuquerque, NM, 87131, dcolman@unm.edu, brandicron@gmail.com, cvesbach@unm.edu, cdahm@sevilleta.unm.edu, dnorthup@unm.edu

3. Scripps Institution of Oceanography, University California San Diego, La Jolla, CA, 92093, drhilton@ucsd.edu

4. Department of Geology, Utah State University, Logan,UT, 84322, tony.lowry@usu.edu

5. Currently at U.S. Geological Survey, Flagstaff, AZ, 86001, rcrow@usgs.gov
\end{abstract}

\begin{abstract}
The discovery of oceanic black (and white) smokers revolutionized our understanding of mid-ocean ridges and led to the recognition of new organisms and ecosystems. Continental smokers, defined here to include a broad range of carbonic springs, hot springs, and fumaroles that vent mantle-derived fluids in continental settings, exhibit many of the same processes of heat and mass transfer and ecosystem niche differentiation. Helium isotope $\left({ }^{3} \mathrm{He} /{ }^{4} \mathrm{He}\right)$ analyses indicate that widespread mantle degassing is taking place in the western U.S.A., and that variations in mantle helium values correlate best with low seismic-velocity domains in the mantle and lateral contrasts in mantle velocity rather than crustal parameters such as GPS, proximity to volcanoes, crustal velocity, or composition. Microbial community analyses indicate that these springs can host novel microorganisms. A targeted analysis of four springs in New Mexico yield the first published occurrence of chemolithoautotrophic Zetaproteobacteria in a continental setting. These observations lead to two linked hypotheses: that mantle-derived volatiles transit through conduits in extending continental lithosphere preferentially above and at the edges of mantle low velocity domains. High $\mathrm{CO}_{2}$ and other constituents ultimately derived from mantle volatiles drive water-rock interactions and heterogeneous fluid mixing that help structure diverse and distinctive microbial communities.
\end{abstract}

Keywords: noble gases, western U.S. mantle, $\mathrm{CO}_{2}$ flux, travertine, Zetaproteobacteria,

\subsection{Introduction}

Black and white smokers in oceanic settings are well-established as strongly coupled systems of mantle degassing, hydrologic mixing, and distinctive biologic communities (Lowell et al., 2008). Geochemical analyses of geothermal and carbonic springs across the western U.S.A. reveal high ${ }^{3} \mathrm{He} /{ }^{4} \mathrm{He}$ ratios indicating pervasive degassing of mantle volatiles also occurs in continental extensional regions (Welhan et al., 1988; Newell et al., 2005). Microbial 
community analyses of continental springs indicate a role for mantle-derived fluids in structuring microbial diversity within them (Colman et al., 2014a). However, such springs with mantle constituents have not yet been considered as systems with coupled processes directly analogous to oceanic smokers. This paper shows that mantle-derived gases in springs correlate spatially with geophysical signals of partial melts in the underlying mantle, and that some of these springs that are rich with mantle-derived volatiles host organisms similar to chemolithoautotrophic organisms that are largely associated with low-temperature marine vent ecosystems. Based on strong similarity to coupled tectonic, hydrologic and biotic systems in oceans, we define continental smokers as carbonic springs, hot springs, and fumaroles that vent mantle-derived fluids in continental extensional settings.

Mantle volatiles degas through conduits and vents in both oceanic and continental extensional settings. In oceanic settings, upwelling of melts derived from geochemically depleted asthenospheric mantle produces mid-ocean ridge basalt (MORB), builds new oceanic lithosphere, and helps drive plate tectonics. Upward transfer of volatiles (e.g. $\mathrm{H}_{2} \mathrm{O}, \mathrm{CO}_{2}, \mathrm{H}_{2}, \mathrm{He}$, $\mathrm{CH}_{4}$ ) accompanies upward transfer of magma through thin oceanic lithosphere with profound hydrochemical and diagenetic effects on oceans. Seismic and magmatic activity, concentrated at ridge crests, facilitates episodic degassing into the oceans. The transport of volatiles is locally focused into gas vents and hot springs emanations (smokers) that take on unique compositions driven by differences in local hydrochemical settings including sulfide-rich black smokers and carbonate-rich white smokers.

Continental extensional environments have many similarities to oceanic ridges but both the structural expression of extension and the associated melt and volatile transfer between asthenosphere and lithosphere are more diffuse and varied due to the greater thickness and heterogeneity of continental crust, and variations in the composition of crustal fluids (e.g. Chiodini et al., 2004; Karlstrom et al., 2013). The conduit systems, transit times, and drivers for transfer of melts and volatiles through continental lithosphere are less well understood. In this paper we use the term continental smokers to include not only volcanic fumaroles and hot springs, but also a wide range of cool to hot carbonic travertine-depositing springs. These carbonic springs are locations of heterogeneous mixing between endogenic (deeply derived) fluids, groundwater, and surface water systems (Crossey et al., 2006; 2009). Similar mantle inputs and mixing and fractionation of fluids and volatiles also take place in continental gas fields (Poreda et al., 1986; Gilfillan et al., 2008; 2009).

Oceanic smokers have fundamentally advanced our understanding of Earth's biosphere, life in extreme environments, and connections to early Earth (Baross and Hoffman, 1985; Nakagawa and Takai, 2008). Similarly, microbial research in Yellowstone geothermal systems has revealed a diverse, yet phylogenetically distinct, terrestrial thermophilic biota leading to extraordinary insights into microbial diversity and biogeography, biogeochemistry, and the evolution of life (e.g. Barns et al., 1994; Hugenholtz et al. 1998; Reysenbach and Shock 2002; Whitaker et al., 2003; Shock et al., 2010; Inskeep et al., 2013). Recent research in lowtemperature, alkaline, serpentinite-hosted continental systems has indicated that underexplored continental systems hold great promise for understanding the interaction of deeply derived fluids, rich in reduced substrates (e.g. $\mathrm{H}_{2}$ ), and the microbial communities associated with them (Suzuki et al., 2013; Crespo-Medina et al. 2014; Meyer-Dombard et al., 2014; Morill et al., 2015). Moreover, microbial phylogenetic analysis of 28 of the carbonic springs described here (Table S1) suggested that some of the springs with highest deep-fluid input contain organisms closely related to chemolithoautotrophs present at marine vent sites and iron-oxidizing biofilms (Colman 
et al., 2014a). Thus, microbiological studies from a wider range of lower-temperature terrestrial springs of the type presented here have rich potential to expand our understanding of subsurface geobiological processes and a fuller spectrum of microbial biodiversity.

Research into transport of mantle volatiles including $\mathrm{CO}_{2}$ to the surface through continental smokers has been underway for some time (e.g., Matthews et al., 1987; Greisshaber et al., 1992; Hilton, 1996), but understanding fluid conduits, the influence of endogenic fluids on near-surface water quality (Earman et al., 2008) and microbial diversity are less well developed. We compile hydrochemical data from springs across the tectonically active western U.S.A., from the western margin of the North American tectonic plate to the Great Plains stable continental interior. To understand fluid conduits better, we seek to quantify and understand the relationships of ${ }^{3} \mathrm{He} /{ }^{4} \mathrm{He}$ values observed in near-surface hydrologic systems to possible controlling factors such as mantle seismic velocity structure (Schmandt and Humphreys, 2010), contemporary crustal stain rate (Kennedy and Van Soest, 2007), proximity to Quaternary volcanoes, and lithology of the crust as inferred from vp/vs seismic velocity ratios (Lowry and Gussinve, 2011).

The noble gases have widespread utility as geochemical tracers (Porcelli et al., 2002) due to chemically inert behavior, relatively low abundance in the solid Earth, and large and diagnostic isotope variations among various reservoirs. Helium consists of two isotopes: ${ }^{3} \mathrm{He}$ (dominantly of primordial origin) and ${ }^{4} \mathrm{He}$ (from radioactive decay). The fluid circulation systems in mid-ocean ridge settings carry a uniform ${ }^{3} \mathrm{He} /{ }^{4} \mathrm{He}$ ratio of $8 \pm 1 \mathrm{R}_{\mathrm{A}}$ (Graham, 2002) where $\mathrm{R}_{\mathrm{A}}=$ atmospheric ${ }^{3} \mathrm{He} /{ }^{4} \mathrm{He}$ ratio of $1.4 \times 10^{-6}$. Deep mantle plume settings (e.g. Hawaii, Iceland, Samoa) can have ${ }^{3} \mathrm{He} /{ }^{4} \mathrm{He}>30 \mathrm{R}_{\mathrm{A}}$ consistent with tapping less degassed lower mantle reservoirs (Graham, 2002). These observations suggest that primordial helium (enriched in ${ }^{3} \mathrm{He}$ ) has been retained by the mantle throughout Earth history, making it a unique tracer of juvenile volatiles (Clarke et al., 1969). In stark contrast, ancient continental cratons are characterized by low ${ }^{3} \mathrm{He} /{ }^{4} \mathrm{He}$ ratios $\left(0.02 \mathrm{R}_{\mathrm{A}}\right)$ indicating that mantle keels insulate cratonic crust from asthenospheric volatiles, so radiogenic ${ }^{4} \mathrm{He}$ accumulates in crustal rocks and fluids over long periods (Andrews, 1985). Helium isotope values $>0.1 \mathrm{R}_{\mathrm{A}}$ in fluids found in continental settings assuming correction for the presence of any air-derived $\mathrm{He}$, are considered to provide unambiguous evidence for a mantle He input (Ballentine et al., 2002) and hence this tracer is valuable for evaluating the influence of endogenic inputs to the hydrochemistry and microbiology of fluids.

\subsection{Methods}

Mantle Tomography Methods. Body-wave tomography models (Schmandt and Humphreys, 2010) and surface wave tomography models (Shen et al., 2013; Yuan and Romanowicz, 2010) were used for comparison with ${ }^{3} \mathrm{He} /{ }^{4} \mathrm{He}$ values. For the higher resolution tomography models using data from EarthScope's Transportable Array ${ }^{3} \mathrm{He} /{ }^{4} \mathrm{He}$ values were compared with upper mantle velocity variations and local relief in upper mantle velocities. Relief was measured as the difference between the minimum and maximum velocity within a radius of $70 \mathrm{~km}$, which is the nominal spacing of the Transportable Array.

Regression of Wedge Plots. The correlations between the ${ }^{3} \mathrm{He} /{ }^{4} \mathrm{He}$ values of springs and the properties of the underlying crust and mantle were determined by linear (least squares) regression through the maximum ${ }^{3} \mathrm{He} /{ }^{4} \mathrm{He}$ values (least mixed/diluted values) over a range of the mantle/crustal values. The regressed points are the maximum ${ }^{3} \mathrm{He} /{ }^{4} \mathrm{He}$ values plotted at the midpoint of the associated bins. The effect of varied bin sizes on the regressions was examined along with the exclusion of bins with less than a critical number of data points ("\#bin" in the 
wedge-plots). These sensitivity tests showed that the slope of the regressed line was not strongly controlled by choice of bin size and minimum number of points in a bin in the cases of the regressions of ${ }^{3} \mathrm{He} /{ }^{4} \mathrm{He}$ value with $v_{\mathrm{p}}, v_{\mathrm{s}}, \mathrm{d} v_{\mathrm{p}}$.

Strain/GPS Map Methods. A GPS-derived estimate of the second invariant of crustal strain rate in southwestern U.S. was used to assess the importance of regional-scale contemporary crustal strain (Kreemer et al., 2012). Farther into the continental interior strain rates are near or below the limits of detection with existing GPS constraints (Berglund et al., 2012), so our analysis of the correlation between ${ }^{3} \mathrm{He} /{ }^{4} \mathrm{He}$ value and crustal strain rate was spatially limited to the southwestern U.S.A.

$v_{P} / v_{S}$ Imaging Methods. Bulk crustal averages of $v_{\mathrm{P}} / v_{\mathrm{S}}$ were derived from joint inversion of crustal receiver functions and gravity data (Lowry and Gussinve, 2011). Stacks of receiver function amplitudes sampled in crustal thickness and $v_{\mathrm{P}} / v_{\mathrm{S}}$ velocity ratio parameter space at each USArray seismic site were modified by likelihood functions derived via optimal interpolation from surrounding sites and gravity modeling. The resulting likelihood-filtered amplitude stacks were used to revise parameter estimates at that site. Parameters were updated at all USArray sites over the course of approximately thirty iterations.

Molecular Microbiological Methods. 454 pyrosequencing was performed on planktonic community DNA extracted from four springs in the Tierra Amarilla spring group of northern New Mexico (Table S1). Planktonic communities were collected by filtering 1 L of spring water with a $0.22 \mu \mathrm{m}$ Sterivex filter (Millipore, Bedford, MA) and DNA was extracted as described by Colman et al. (2014a). 454 pyrosequencing was performed at Research and Testing Laboratories (Lubbock, TX) using universal bacterial PCR primers, quality-filtering steps, and analytical steps described elsewhere (Van Horn et al. 2014). Briefly, 454 pyrosequencegenerated 16S rRNA gene reads were clustered into operational taxonomic units (OTUs, defined at the $97 \%$ similarity level) and representative sequences for each OTU were compared against the Greengenes reference database to assign taxonomy. Further phylogenetic analysis of surface and subsurface samples at Twin Mound East Spring was conducted using nearly full-length bacterial 16S rRNA gene sequences generated with universal bacterial PCR primers as described in Northup et al. (2010), and sequenced in both directions at the Washington University Genome Sequencing Facility. Sequences were edited and assembled into contigs using Sequencher (v.4.8, Gene Codes, Ann Arbor, Michigan). The 16S rRNA gene sequences were chimera screened and phylogenetically analyzed as in Colman et al. (2014b) and a maximum likelihood tree was constructed for the Proteobacteria representatives from both samples using the GTR + G + I DNA substitution model.

Water Chemistry Methods. Geochemical analyses were conducted and compiled for volatiles and water chemistry in carbonic and geothermal springs and groundwaters across the western U.S.A. This set of springs and groundwaters includes hot springs and hydrothermal fields, cool travertine-depositing springs, gas fields, and diffuse emanations into groundwater (Table S1). Noble gas data, especially ${ }^{3} \mathrm{He} /{ }^{4} \mathrm{He}$ data, provide unequivocal evidence for the presence of mantle gases in the near-surface hydrologic system if air-corrected ${ }^{3} \mathrm{He} /{ }^{4} \mathrm{He}$ ratios are $>0.1 \mathrm{R}_{\mathrm{A}}(>1.3 \%$ of MORB; Ballentine et al., 2002). Carbon content of springs was analyzed in terms of total dissolved inorganic carbon $\left(\mathrm{DIC}=\mathrm{HCO}_{3}+\mathrm{H}_{2} \mathrm{CO}_{3}\right.$ as modeled using U.S.G.S. code Phreec C).

\subsection{Results}


Figure 1 plots ${ }^{3} \mathrm{He} /{ }^{4} \mathrm{He}$ values of 714 springs and groundwaters, including 19 new analyses, on a tomographic image of P-wave mantle velocity structure at $80 \mathrm{~km}$, a depth likely to contain partial melt in much of the region (Schmandt and Humphreys, 2010). This map shows widespread mantle degassing in all tectonic provinces across the western U.S.A. Highest ${ }^{3} \mathrm{He} /{ }^{4} \mathrm{He}$ values, up to $16 \mathrm{R}_{\mathrm{A}}$, are observed at Yellowstone (Craig et al., 1978; Chiodini et al., 2012) consistent with a plume origin for the Yellowstone hotspot (Craig et al., 1978; Schmandt et al., 2012). As shown in Figure 1 and Table $S 1,{ }^{3} \mathrm{He} /{ }^{4} \mathrm{He}$ values close to MORB $\left(6-8 \mathrm{R}_{\mathrm{A}}\right)$, are found in the Cascadia arc $\left(8 \mathrm{R}_{\mathrm{A}}\right)$, San Andreas and Walker Lane plate boundary fault zones including the Salton Trough $\left(6 \mathrm{R}_{\mathrm{A}}\right)$ and locally in the Basin and Range and the Jemez Caldera of the Rio Grande rift $\left(6 \mathrm{R}_{\mathrm{A}}\right)$. Other intraplate areas also show significant mantle degassing, for example, through natural gas fields on the Great Plains $\left(4 \mathrm{R}_{\mathrm{A}}\right.$ at Bravo Dome; $3 \mathrm{R}_{\mathrm{A}}$ at Hugoton Field), in groundwaters in southern New Mexico $\left(4 \mathrm{R}_{\mathrm{A}}\right)$, in hot springs of the Colorado Rocky Mountains $\left(5.9 \mathrm{R}_{\mathrm{A}}\right)$, and in the dissected hydrologic system of the Grand Canyon $\left(1 \mathrm{R}_{\mathrm{A}}\right)$. The springs that were selected for analyses included cool as well as warm or hot springs, with temperatures ranging from 20 to $>60{ }^{\circ} \mathrm{C}$. Most of the sampled carbonic springs have ${ }^{3} \mathrm{He} /{ }^{4} \mathrm{He}$ values $>0.1 \mathrm{R}_{\mathrm{A}}$ (Fig. 1), a value considered to represent an unambiguous mantle He input (Ballentine et al., 2002). Lowest ${ }^{3} \mathrm{He} /{ }^{4} \mathrm{He}$, consistent with cratonic values, were found in regions underlain by lithosphere with high relative mantle velocities; $0.05 \mathrm{R}_{\mathrm{A}}$ in Archean Wyoming province and Great Plains, $0.03 \mathrm{R}_{\mathrm{A}}$ in SE New Mexico and northern Texas, and $0.02 \mathrm{R}_{\mathrm{A}}$ in the Canadian Shield.

We examine additional possible controls on mantle degassing by graphing ${ }^{3} \mathrm{He} /{ }^{4} \mathrm{He}$ variations relative to several mantle and crustal geophysical properties (Fig. 2 and Figs. S1-S6). Most of the mantle datasets result in a wedge-plot relationship whereby the highest ${ }^{3} \mathrm{He} /{ }^{4} \mathrm{He}$ ratios occur above regions of low relative mantle velocity. The highly variable ${ }^{3} \mathrm{He} /{ }^{4} \mathrm{He}$ values within individual tectonic provinces are interpreted to reflect fluid mixing that can lower ${ }^{3} \mathrm{He} /{ }^{4} \mathrm{He}$ by dilution of mantle-derived fluids with the crustal ${ }^{4} \mathrm{He}$ reservoir. Yellowstone provides an excellent example of an extreme range of ${ }^{3} \mathrm{He} /{ }^{4} \mathrm{He}$ values manifesting mixing in the near-surface groundwater system even in hydrothermal areas known to have fluids with the highest ${ }^{3} \mathrm{He} /{ }^{4} \mathrm{He}$ values. Figure 2 plots the highest (least diluted/mixed) ${ }^{3} \mathrm{He} /{ }^{4} \mathrm{He}$ values relative to mantle $\mathrm{P}$-wave velocity for different regions (see section 1.2 for regression methods). These data show that maximum ${ }^{3} \mathrm{He} /{ }^{4} \mathrm{He}$ values occur in regions of low $\mathrm{P}$-wave $\left(\mathrm{r}^{2}=0.84\right)$ and $\mathrm{S}$-wave $\left(\mathrm{r}^{2}=0.94\right)$ velocity. The presence of Quaternary volcanism in many regions of low mantle seismic velocities suggests a close association between partial melting and high mantle volatile inputs at the scale of tectonic provinces. However, $40 \%$ of the sampled springs with significant mantle He are $>50 \mathrm{~km}$ from Quaternary volcanics in NAVDAT (Fig. S2) suggesting that diffuse degassing and fault conduits, as well as emanations proximal to volcanic fields, are both important for volatile loss.

We also examine correlations between ${ }^{3} \mathrm{He} /{ }^{4} \mathrm{He}$ variations and mantle velocity gradients. The western U.S.A. has very sharp $(<100-\mathrm{km}$-wide) mantle velocity contrasts (maximum of $11 \%$ for $v_{\mathrm{s}}, 6 \%$ for $v_{\mathrm{p}}$ ) that seem to necessitate ongoing mantle flow and/or melt and volatile transfer through the lithosphere. Wedge-plot correlations (Fig. S3) between maximum velocity variations within a $70 \mathrm{~km}$ radius and ${ }^{3} \mathrm{He} /{ }^{4} \mathrm{He}$ values show that mantle degassing also correlates well with $\mathrm{P}$-wave velocity relief $\left(\mathrm{r}^{2}=0.82\right)$ and $\mathrm{S}$-wave velocity relief $\left(\mathrm{r}^{2}=0.79\right)$. These velocity variations would scale to $500-700{ }^{\circ} \mathrm{C}$ thermal contrasts if their origin is assumed to be subsolidus thermal variations (Cammarano et al., 2003). However, since a melt phase is likely present (Schmandt and Humphreys, 2010), thermal contrasts are less and we interpret the regions 
of high velocity gradient to be conduits for melt and volatile transfer from the mantle to the crust (Crow et al., 2011). An inverse correlation with lithospheric thickness (Yuan and Romanowicz, $2010)$ is fairly good $\left(r^{2}=0.7\right.$; Fig. S4) suggesting that lithospheric thinning enhance volatile transfer.

We also test for a crustal role in accounting for lateral variations in ${ }^{3} \mathrm{He} /{ }^{4} \mathrm{He}$ ratios, such as the proposed correlation between ${ }^{3} \mathrm{He} /{ }^{4} \mathrm{He}$ values in the Nevada Basin and Range and crustal GPS velocity (Kennedy and Van Soest, 2007). In this model, a higher crustal strain rate was envisioned to facilitate upward volatile transport through a relatively impermeable lower crustal ductile layer, which was viewed previously as a barrier to mantle inputs. Correlations are good in parts of the Basin and Range $\left(r^{2}=0.7\right.$; Fig. S5). However, the relationship breaks down in the Rocky Mountain region where ${ }^{3} \mathrm{He} /{ }^{4} \mathrm{He}$ values are high and contemporary crustal strain rates are near or below the limits of detection of GPS data. This corroborates studies (Wannamaker et al., 2008) that show that fluids migrate at a range of scales during ductile deformation through transient brittle vein and shear zone networks, and along grain boundaries.

Seismic $v_{\mathrm{P}} / v_{\mathrm{S}}$ ratios are sensitive to quartz, the weakest mineral commonly found in ductile crust and hence crustal composition may act to localize deformation (Lowry and Gussinve, 2011). We compare crustal $v_{\mathrm{P}} / v_{\mathrm{S}}$ to ${ }^{3} \mathrm{He} /{ }^{4} \mathrm{He}$ (Fig. S6) to test whether bulk crustal composition influences the ability of mantle volatiles to reach the surface. The maximum correlation is very low $\left(r^{2}=0.13\right)$ suggesting that crustal lithology does not have a first-order relationship to the variable distribution of ${ }^{3} \mathrm{He} /{ }^{4} \mathrm{He}$ at the surface.

The carrier gas for transit of mantle $\mathrm{He}$ is inferred to be predominantly $\mathrm{CO}_{2}$ and $\mathrm{CO}_{2} / \mathrm{H}_{2} \mathrm{O}$ supercritical fluid associated with mantle partial melting and regions of high heat flow (e.g., Sherwood Lollar et al., 1997; Newell et al., 2005). One selection criteria for sampling and tabulating springs was to find carbonic springs with elevated $\mathrm{CO}_{2}$ partial pressures. Springs reported here have $\mathrm{P}_{\mathrm{CO} 2}$ of $>10-100$ times atmospheric values $\left(10^{-3.5}\right.$ atm $)$ and many have $\mathrm{P}_{\mathrm{CO} 2}$ $\sim 10^{\circ}$ (fluids equilibrated with a near pure $\mathrm{CO}_{2}$ gas phase). Many of these springs host travertine deposits that also reflect high $\mathrm{CO}_{2}$ content and persistent degassing for millions of years (Crossey et al., 2006).

Figure 3 is a cross section of the Rio Grande rift that illustrates the proposed pathways for transfer of mantle volatiles. We infer that both $\mathrm{He}$ and $\mathrm{CO}_{2}$ can be conveyed from the asthenosphere to the lithosphere via dike and sill networks that transmit basaltic melts and associated volatiles. Lithospheric shear zones also convey volatiles (Kennedy and Van Soest; 2007). Melt and heat transfer induces further melting of mantle lithosphere such that it is generally difficult to determine the extent to which mantle He is recently delivered from asthenosphere (last few million years; Kennedy et al., 1997) and/or can be mixed with stored subcrustal lithospheric mantle volatiles (Reid and Graham, 1996). Likewise, $\mathrm{CO}_{2}$ can be a mixture representing both young magmatic fluids and stored $\mathrm{CO}_{2}$ (Humphreys et al., 2003). Seismicity near the brittle-ductile transition both facilitates and is a symptom of upward ascent of volatiles. Empirical data suggest that endogenic fluid ascent is not uniform but occurs preferentially in permeable pathways as suggested by the distribution of springs and travertines along faults and near magma bodies. Mixing of endogenic fluids with epigenic fluids takes place cryptically in aquifers (Williams et al., 2013), so travertine -depositing cool springs as well as geothermal springs are surface manifestations of variably mixed waters that carry a significant but difficult to quantify endogenic component.

The origin of the carbon in the deeply sourced $\mathrm{CO}_{2}$ component can be estimated by examining its relationship to ${ }^{3} \mathrm{He}$ via the $\mathrm{CO}_{2} /{ }^{3} \mathrm{He}$ ratio. MORB has a narrow range of $\mathrm{CO}_{2} /{ }^{3} \mathrm{He}$ 
( 2 to $7 \times 10^{9}$ ), whereas continental crustal fluids are characterized by highly variable $\mathrm{CO}_{2} /{ }^{3} \mathrm{He}$ ranging from $10^{9}$ to $10^{14}$. A 5-order-of-magnitude spread of $\mathrm{CO}_{2} /{ }^{3} \mathrm{He}$ in the western U.S.A. shows that there is not a simple systematic relationship between ${ }^{3} \mathrm{He} /{ }^{4} \mathrm{He}$ and $\mathrm{CO}_{2} /{ }^{3} \mathrm{He}$ and suggests heterogeneous distribution of $\mathrm{CO}_{2}$. Fractionation of the $\mathrm{CO}_{2} /{ }^{3} \mathrm{He}$ ratio is likely as, or more important than, fluid mixing such that binary (O’Nions and Oxburgh, 1988) and ternary (Sano and Marty, 1995) mixing models provide incomplete explanations for $\mathrm{CO}_{2} /{ }^{3} \mathrm{He}$ variability (Hilton, 1996; Sherwood-Lollar et al., 1997).

Another method to help quantify the components of the $\mathrm{CO}_{2}$ load uses water chemistry (Chiodini et al., 2004; Crossey et al., 2009). First, the dissolved inorganic carbon (DIC) derived from carbonate dissolution in the aquifer is calculated $\left(\mathrm{C}_{\mathrm{carb}}=\mathrm{Ca}+\mathrm{Mg}-\mathrm{SO}_{4}\right)$, defining remaining $\mathrm{CO}_{2}$ as external carbon $\left(\mathrm{C}_{\mathrm{ext}}=\mathrm{DIC}_{\text {total }}-\mathrm{C}_{\text {carb }}\right)$. Second, $\mathrm{C}$ isotopes are used to estimate soil/ organic contributions $\left(\mathrm{C}_{\text {org }}\right)$ versus the deeply-derived endogenic component $\left(\mathrm{C}_{\text {endo }}\right)$. Karlstrom et al. (2013) showed different calculated proportions of the $\mathrm{C}_{\mathrm{ext}}$ component of the DIC for the Colorado Rocky Mountains and Colorado Plateau reflecting different aquifer types, but endogenic (deeply sourced) $\mathrm{CO}_{2}$ was important in the carbonic springs of both regions. DIC $\mathrm{t}_{\text {total }}$, multiplied by spring discharge, gives a minimum estimate of $\mathrm{CO}_{2}$ flux via the springs. As examples, a total of $10^{9}$ moles/year of $\mathrm{CO}_{2}$ is being contributed from the Rocky Mountains (Karlstrom et al., 2013), $10^{8}$ moles/year from the southern Colorado Plateau springs (Crossey et al., 2009) and $10^{11}$ moles/year from Yellowstone (Werner and Brantley, 2003). Thus, even this small subset of western U.S degassing shows that diffuse $\mathrm{CO}_{2}$ contributions from extensional continental regions are an underappreciated but globally significant output of $\mathrm{CO}_{2}$ from the solid Earth compared to subduction zones $\left(1.5 \times 10^{12} \mathrm{~mol} / \mathrm{yr}\right)$ and mid-ocean ridges $\left(2.2 \times 10^{12} \mathrm{~mol} / \mathrm{yr}\right)$ (Hilton et al., 2002).

\subsection{Geomicrobiology}

The geomicrobiology of continental smokers offers considerable opportunity for the discovery and characterization of understudied microbial communities. Fluid-rock reactions determine the composition and distribution of metabolic niches in hydrothermal ecosystems such that the potential for variation within continental rocks is likely greater than in basalt/serpentinite/peridotite - dominated submarine systems. A microbial community survey was conducted on $28 \mathrm{cool}$ and warm springs in the western U.S.A in diverse geologic provinces that demonstrated differential mixing of deeply sourced fluids with shallowly circulated water (Colman et al., 2014a). The springs harbored diverse taxa, although the metabolically diverse Proteobacteria phylum dominated the dataset $(81.2 \%$ of all bacterial $16 \mathrm{~S}$ rRNA gene sequences recovered). Each spring's microbial community was largely distinct from others, but correlations between community composition and spring geochemical properties were observed. In particular, geochemical proxies for the amount of endogenic fluid input into springs correlated with taxonomic composition. Springs with lower endogenic fluid input (e.g. lower modeled equilibrium $\mathrm{P}_{\mathrm{CO} 2}$ ) were represented by ubiquitously distributed freshwater heterotrophic taxa; springs with higher levels of $\mathrm{P}_{\mathrm{CO} 2}$ contained a disproportionate number of taxa that could not be classified at the phylum level, as well as indicator taxa similar to $16 \mathrm{~S}$ rRNA gene sequences from uncultivated Betaproteobacteria associated with iron-oxidizing biofilms. Springs with the highest levels of modeled $\mathrm{P}_{\mathrm{CO} 2}$ also contained organisms related to the Zetaproteobacteria, which have previously only been detected in marine environments, predominantly in iron-oxidizing biofilms at warm vent sites on the ocean floor (Emerson et al., 2010). Culture-independent analyses have elucidated large global distributions of the Zetaproteobacteria, but only a single 
species of the marine autotrophic iron-oxidizing species Mariprofundus ferrooxydans, containing four strains, has been characterized (Singer et al., 2011). The newly characterized Zetaproteobacteria are stalk-forming iron-oxidizing bacteria that play a major role in biogenic $\mathrm{Fe}$ (III) mineral formation in deep-sea hydrothermal vents (Emerson et al., 2010), and have received considerable research attention for their role in open ocean biogenic Fe-oxidation.

A subset of the 28 springs analyzed in Colman et al. (2014a) were chosen for more indepth analyses because of their potential for harboring novel bacterial taxa. A spring group near San Ysidro, New Mexico with moderate levels of endogenic fluid input: ${ }^{3} \mathrm{He} /{ }^{4} \mathrm{He}$ up to $0.4 \mathrm{R}_{\mathrm{A}}$, $\mathrm{P}_{\mathrm{CO} 2}$ up to 0.93 (nearly pure $\mathrm{CO}_{2}$ ), and moderately high values of geothermal $\mathrm{Br}$, $\mathrm{Li}$, and $\mathrm{B}$ was analyzed using both Sanger and 454 DNA pyrosequencing (Cron, 2011). Bacterial community composition varied considerably, even among geographically close (within $\sim 1 \mathrm{~km}$ ) springs (Fig. 4). Mariprofundus-like taxa dominated the Twin Mound East spring (Surface and Deep samples; Fig. 4 and Table S2). The other three springs were dominated by other Proteobacteria taxa. One spring contained a minor (0.2\%) Mariprofundus-like population, but was dominated by Betaproteobacteria that could not be classified beyond the rank of class. Further analysis of the single unclassified Betaproteobacteria OTU that constituted 56\% of the bacterial 16S rRNA gene sequences in the spring indicated it was $98 \%$ similar to a $16 \mathrm{~S}$ rRNA gene sequence from the microaerobic, autotrophic, iron-oxidizing Gallionella capsiferriformans strain ES-2 (Emerson et al., 2013). The other two springs were dominated by photosynthesising Cyanobacteria and heterotrophic taxa of the Gammaproteobacteria. Phylogenetic analysis of near full-length 16S rRNA genes from the spring group samples containing Mariprofundus-like populations indicated that the spring Zetaproteobacteria belonged to two monophyletic clades (TA_zeta_group1/2, Fig. 5). While the two clades were affiliated with the Zetaproteobacteria, they were distantly related to marine-vent associated uncultured clones and Mariprofundus isolates, and potentially represent new terrestrial-associated genera within the Zetaproteobacteria that are distinct from marine-associated relatives. The present study is the first published report of Zetaproteobacteria in a continental setting.

The spring systems near San Ysidro, New Mexico provide a distinct hydrogeochemical environment that is necessary for the microaerobic chemolithoautotrophic niches employed by both the iron-oxidizing (FeOB) Zeta- and Betaproteobacteria found here (Emerson et al., 2010). Although Zetaproteobacteria have been considered strictly marine iron-oxidizing and Betaproteobacteria strictly freshwater FeOB, our results indicate that continental spring ecosystems influenced by endogenic fluids provide important opportunities to expand the biodiversity, biogeographic and ecological context of iron-oxidizing bacteria. Further investigation of these populations may elucidate whether these continental Zetaproteobacteria groups exhibit novel physiological adaptations to their continental spring environments. We predict they will be found in other underexplored continental subsurface ecosystems and appreciably contribute to iron cycling in continental as well as marine systems.

\subsection{Discussion}

Conduits for volatiles. Highest ${ }^{3} \mathrm{He} /{ }^{4} \mathrm{He}$ values of $\sim 15 \mathrm{R}_{\mathrm{A}}$ are associated with the active volcanic center in Yellowstone; these values reinforce models for a plume origin for Yellowstone. High ${ }^{3} \mathrm{He} /{ }^{4} \mathrm{He}$ values elsewhere in the western U.S. approach MORB values of 8 $\mathrm{R}_{\mathrm{A}}$ above the Cascadia subduction zone and San Andreas transform and indicate that plate boundaries provide zones for flux of asthenosphere-derived volatiles. The positive correlations between measured ${ }^{3} \mathrm{He} /{ }^{4} \mathrm{He}$ in springs and groundwaters with both low mantle velocity domains 
and sharp gradients in mantle velocity suggest diffuse degassing even in areas away from active volcanic regions and plate margins. This is perhaps surprising given the thickness of continental lithosphere. The combination of widespread but spatially partitioned mantle degassing in the western U.S leads us to a hypothesized conduit system similar to that shown in Figure 3 involving basalt and volatile transfer from the mantle to the crust directly by melt transfer. The absence of correlations between ${ }^{3} \mathrm{He} /{ }^{4} \mathrm{He}$ and GPS-measured crustal deformation suggests that ductile lower crust need not be a barrier to volatile flux. Preferential intracontinental mantle degassing along structural boundaries (Basin and Range of Nevada, Wasatch Front of Utah, Rio Grande rift, and Rocky Mountains), as well as the association of travertine-depositing carbonic springs with faults, suggest that the upper crustal conduit systems involve deeply penetrating extensional fault networks.

Influences of endogenic fluids on microbial communities. Significant correlations shown by Colman and others (2014a) between hydrochemistry $\left(p \mathrm{CO}_{2},[\mathrm{Mg}], \mathrm{C}_{\text {ext }}\right)$ and microbial community composition suggests that the spring communities are influenced by endogenic fluid inputs that are carbonic, reduced, and high in salts and metals, for example [Mg]. Similar parameters have been shown to reflect degree of mixing with hydrothermal fluids in marine systems (Mottl \& Wheat, 1994) where hydrochemistry is also highly correlated with diffuse vent microbial community composition at the Axial Seamount marine site (Opatkiewicz et al., 2009). $\mathrm{C}$ isotope analyses indicate that the high total dissolved inorganic carbon (DIC) in our springs is a mixture of $\mathrm{C}$ derived from dissolution of carbonate, soil/ organic sources, and endogenic sources, but that endogenic sources often dominate (e.g. mean of $76 \%$ in Colorado hot springs; Karlstrom et al., 2013). Even where the percentage of carbon derived from dissolution of carbonate is higher (e.g. a mean of $42 \% \mathrm{C}_{\text {carb }}$ in the carbonate aquifers of the Colorado Plateau; Crossey et al., 2009), it is the high endogenic $\mathrm{C}$ component (33\% $\mathrm{C}_{\text {endo }}$ for the Colorado Plateau) that promotes the dissolution of carbonate in the aquifer and leads to formation of travertine at spring vents. Thus, the carbonic character of continental smokers, and their common association with travertine, are considered to be reflections of inputs ultimately derived from magmatic sources, as also supported by the ${ }^{3} \mathrm{He} /{ }^{4} \mathrm{He}$ ratios. The increased concentrations of $\mathrm{CO}_{2}$ and cotransported mantle-derived gases and solutes such as $\mathrm{H}_{2}, \mathrm{Fe}^{+2}, \mathrm{H}_{2} \mathrm{~S}, \mathrm{CH}_{4}$ and $\mathrm{S}^{\mathrm{o}}$ promote reducing conditions and are available to be used metabolically by chemolithotrophs. These processes are similar to those at marine hydrothermal vents where chemolithotroph metabolic substrates are abundant due to the venting of deeply circulated sea water that has gained reduced chemical species from water-rock interactions (Jannasch \& Mottl, 1985). Colman et al. (2014a) show a wide diversity of Bacteria and Archaea in five provinces in the western United States within springs that exhibit high endogenic fluid components. The heterogeneity in hydrochemistry and community composition among the springs support the general hypothesis that the extent and character of the endogenic fluid input is an important community structuring factor. Thus, the diverse microbial systems of continental smokers may bridge the ecological dynamics of surficial oxidized freshwater, reduced subsurface conditions, mesothermal, and hyperthermal springs, and even between marine and non-marine hydrothermal vent settings.

The results reported here contribute to the growing body of literature that suggests lowtemperature continental springs and lakes sustained by deeply sourced fluids harbor distinctive microbial ecosystems (e.g Antony et al. 2013; Suzuki et al. 2013; Crespo-Medina et al. 2014; Morrill et al. 2014; Meyer-Dombard et al. 2015). These low-temperature systems hold promise for understanding novel biodiversity and the geobiological processes that are influenced by deep subsurface geologic processes. High-temperature volcanically driven systems (marine and 
continental) provided the first insights into chemolithotrophically dominated ecosystems that are reliant on metabolic substrates derived from water-rock interactions (e.g. Hugenholtz et al., 1998). The discovery of low-temperature, alkaline, serpentinite-hosted marine vents further widened the spectrum of microbially dominated ecosystems reliant on solutes and volatiles derived from deep subsurface processes and provide a low-temperature continental analog to serpentinite marine-hosted vents (Kelley et al. 2005). Recent results from continental serpentinite-hosted systems (Suzuki et al., 2013; Crespo-Medina et al. 2014; Meyer-Dombard et al., 2014; Morill et al., 2015) and saline and alkaline lakes, as well as springs, of the East African Rift (Antony et al., 2013; Dadheech et al., 2013) have documented distinctive continental lowtemperature geobiological environments. Our work further shows that carbonic springs of the western U.S., rich with deeply-sourced fluids, can host microbial ecosystems that have been thus far underexplored, but hold promise for insight into the interaction of microorganisms and deeply-sourced fluids rich with reduced metabolic substrates for chemolithotrophy.

\subsection{Conclusions}

Continental smokers are vents that discharge mantle-derived fluids in extensional continental settings. They are analogous to marine smokers in heat and mass transfer via asthenosphere-lithosphere interactions, and they can support unique microbial metabolic strategies as well as ecosystem niche differentiation. A correlation of sharp mantle velocity gradients with high ${ }^{3} \mathrm{He} /{ }^{4} \mathrm{He}$ values suggests that volatiles may transit through narrow mantle conduits. Microbiological results from four springs in New Mexico document the first published occurrence of putatively chemolithotrophic iron-oxidizing Zetaproteobacteria in a continental setting. Future analyses of similar springs from tectonically-active regions worldwide have a rich potential to expand our understanding of continental biodiversity and the geobiological interactions of microorganisms and their subsurface-influenced environments.

\section{References Cited}

Andrews, J.N. The isotopic composition of radiogenic helium and its use to study groundwater movements in confined aquifers. Chem. Geol. 49, 339-351 (1985).

Antony, C.P. et al. Microbiology of Lonar Lake and other soda lakes. ISME J, 7, 468476. (2013).

Ballentine, C. J., Burgess, R. \& Marty, B. in Noble Gases in Geochemistry and Cosmochemistry (eds Porcelli, D. R., Ballentine, C. J. \& Weiler, R.) (Geochem. Soc. and Mineral.Soc.Am. 539-614 (2002).

Barns S.M., Fundyga R.E., Jeffries M.W., Pace N.R. Remarkable archaeal diversity detected in a Yellowstone National Park hot spring environment. Proc. Natl. Acad. Sci. 91, 16091613 (1994).

Baross, J.A., Hoffman, S.E. Submarine hydrothermal vents and associated gradient environments as sites for the origin and evolution of life. Origins of life 15, 327-345 (1985).

Berglund, H.T., et al., Distributed deformation across the Rio Grande Rift, Great Plains, and Colorado Plateau: Geology, 40, 23-26 (2012). 
Cammarano, F., Goes, S., Vacher, P., and Giardini, D. Inferring upper-mantle temperatures from seismic velocities. Phys. Earth \& Plan. Int. 138, 197-222 (2003).

Chiodini G, Cardellini C, Amato A, Boschi E, Caliro S, Frondini F, Ventura, G. Carbon dioxide Earth degassing and seismogenesis in central and southern Italy. Geophys. Res.Lett. 31, (2004)

Chiodini, G., Caliro, S., Lowenstern, J.B., Evans, W.C., Bergfeld, D., Tassi, F., and Tedesco, D., Insights from fumerole gas geochemistry on the origin of hydrothermal fluids on the Yellowstone Plateau. Geochim et Cosmochim Acta. 89, 265-278 (2012).

Clarke, W.B., Beg, M.A., and Craig, H. Excess ${ }^{3} \mathrm{He}$ in the sea; evidence for terrestrial primordial helium. Earth \& Planet. Sci. Lett. 6, 213-220 (1969).

Colman, D.R., Garcia, J.R., Crossey, L.J., Karlstrom, K.E., Jackson-Weaver, O, TakacsVesbach, T. An analysis of geothermal and carbonic springs in the western United States sustained by deep fluid inputs. Geobiology, 12, 83-98 (2014a).

Colman, D.R., Thomas, R., Maas, K.R., and Takacs-Vesbach, C.D. Detection and analysis of elusive members of a novel and diverse archaeal community within a thermal spring streamer consortium. Extremophiles, Advance Online Publication. doi: 10.1007/s00792-0140715-0 (2014b).

Craig, H., Lupton, J.E., Welhan, J.A., and Poreda, R., 1978. Helium isotope ratios in Yellowstone and Lassen park volcanic gases. Geophys. Res.Lett. 5, 897-900 (1978).

Crespo-Medina, M., et al. Insights into environmental controls on microbial communities in a continental serpentinite aquifer using a microcosm-based approach. Front Microbiol. 5: 604 (2014).

Cron B.R. Geochemical characteristics and microbial diversity of $\mathrm{CO}_{2}$-rich mound spring of the Tierra Amarilla anticline, New Mexico. M.S. thesis, University of New Mexico, Albuquerque (2011).

Crossey L.J., et al., Dissected hydrologic system at the Grand Canyon: Interaction between deeply derived fluids and plateau aquifer waters in modern springs and travertine. Geology 34, 25-28 (2006).

Crossey, L.J., Karlstrom, K.E., Springer, A., Newell, D., Hilton, D., and Fischer, T. Degassing of mantle-derived $\mathrm{CO}_{2}$ and ${ }^{3} \mathrm{He}$ from springs in the southern Colorado Plateau region-Flux rates, neotectonics connections, and implications for understanding the groundwater system. Geol. Soc. Am. Bull. 121, 1034-1053 (2009).

Crow, R., Karlstrom, K., Asmerom, Y., Schmandt, B., Polyak, V., and DuFrane, S. A. Shrinking of the Colorado Plateau via lithospheric mantle erosion: Evidence from $\mathrm{Nd}$ and $\mathrm{Sr}$ isotopes and geochronology of Neogene basalts. Geology 39, 27-30 (2011).

Dadheech, P.K., et al. Cyanobacterial diversity in the hot spring, pelagic and benthic habitats of a tropical soda lake. FEMS Microbiol Ecol, 85, 389-401 (2013). 
Earman, S., McPherson, J.O.L., Phillips, F.M., Ralser, S., Herrin, J.M., and Broska, J. Tectonic influences on ground water quality: Insight from complementary methods: Ground Water, 46, 354-371 (2008).

Emerson, D., Field, E.K., Chertkov, O., Davenport, K.W., Goodwin, L., Munk, C., Nolan, M. and Woyke, T. Comparative genomics of freshwater Fe-oxidizing bacteria: implications for physiology, ecology and systematics. Front Microbiol, 4, 254 (2013).

Emerson, D., Fleming, E.J. and McBeth, J.M. Iron-Oxidizing Bacteria: An Environmental and Genomic Perspective. Annu Rev Microbiol, 64, p. 561-583 (2010).

Gilfillan, S. M. V. et al. The noble gas geochemistry of natural CO2 gas reservoirs from the Colorado Plateau and Rocky Mountain provinces, USA. Geochim. Cosmochim. Acta 72, 1174-1198 (2008).

Gilfillan, S.M. et al. Solubility trapping in formation water as dominant $\mathrm{CO}_{2}$ sink in natural gas fields. Nature 458, 614-618 (2009).

Graham, D.W. Noble gas isotope geochemistry of mid-ocean ridge and ocean island basalts: Characterization of mantle source reservoirs. Rev. Min. \& Geochem. 47, 481-538 (2002).

Greisshaber, E., O’Nions, R.K., and Oxburgh, E.R. Helium and carbon isotope systematics in crustal fluids from the Eifel, the Rhine Graben, and Black Forest, F.G.R. Chem. Geol. 99, 213-235 (1992).

Hilton, D.R. The helium and carbon isotope systematics of a continental geothermal system: results from monitoring studies at Long Valley caldera (California, U.S.A.) Chem. Geol. 127, 269-295 (1996).

Hilton, D. R., Fischer, T. P. and Marty, B. (2002) Noble gases and volatile recycling at subduction zones. Noble Gases in Cosmochemistry and Geochemistry (Porcelli, D., Ballentine, C. J. and Wieler, R., eds.), Mineralogical Society of America, Washington, D.C.

Hugenholtz, P., Pitulle, C., Hershberger, K.L. and Pace, N.R. Novel division level bacterial diversity in a Yellowstone hot spring. J. Bacteriol. 180, 366-376 (1998).

Humphreys, E., et al. How Laramide-Age Hydration of North American Lithosphere by the Farallon Slab Controlled Subsequent Activity in the Western United States. Internat.Geol. Rev. 45, 575-595 (2003).

Inskeep, W.P., Jay, Z.J., Tringe, S.G., Herrgård, M. J., Rusch, D.B., YNP Metagenome Project Steering Committee and Working Group Members. The YNP Metagenome Project: Environmental Parameters Responsible for Microbial Distribution in the Yellowstone Geothermal Ecosystem. Front Microbiol, 4 (2013).

Jannasch, H.W., Mottl, M.J. Geomicrobiology of Deep-Sea Hydrothermal Vents. Science 229, 717-725 (1985). 
Karlstrom, K.E., Crossey, L.C., Hilton, D.R., and Barry, P.H. Active mantle degassing above the Aspen Anomaly of Colorado: Mantle to surface interconnections and implications for neotectonics of the Rocky Mountains. Geology 41, 495-498 (2013).

Kelley, D.S. et al. A Serpentinite-Hosted Ecosystem: The Lost City Hydrothermal Field. Science. 307, 1428-1434 (2005).

Kennedy, B.M., Reynolds, J.H., and Smith, S.P. Helium isotopes: Lower Geyser Basin, Yellowstone National Park. J. Geophys. Res. 92, 12,477-12,489 (1987).

Kennedy, B.M., and van Soest, M.C. Flow of mantle fluids through the ductile lower crust: Helium isotope trends. Science 318, 1433-1436 (2007).

Kennedy, B.M. et al., Mantle fluids in the San Andreas fault system, California. Science 278, 1278-1281 (1997).

Kerrick, D.M. Present and past nonanthropogenic $\mathrm{CO}_{2}$ degassing from the solid Earth. Rev. Geophys. 39, 565-585 (2001).

Kreemer, C., et al., A geodetic strain rate model for the southwestern United States, Nevada Bur.Mines \& Geology, M178 (2012).

Lowell, R.P., Seewald, J.S., Metaxas, A., Perfit, M.R. et al. Magma to Microbe: Modeling Hydrothermal Processes at Ocean Spreading Centers. AGU Geophys. Mon. 178, 285 (2008).

Lowry, A. R., and Gussinve, M. P. The role of crustal quartz in controlling Cordilleran deformation. Nature 471, 7338 ( 2011).

Meyer-Dombard, D.R., et al. High pH microbial ecosystems in a newly discovered, ephemeral, serpentinizing fluid seep at Yanartaş (Chimera), Turkey. Front. Microbiol. 5:723 (2015).

Mathews, A., Foillac, C., Hill, R., O'Nions, R.K., and Oxburgh, E.R., Mantle derived volatiles in continental crust: the Massif Central of France. Earth \& Planet. Sci. Lett. 85 117-128 (1987).

Morrill, P.L. et al. Investigations of potential microbial methanogenic and carbon monoxide utilization pathways in ultra-basic reducing springs associated with present-day continental serpentinization: the Tablelands, NL, CAN. Front. Microbiol. 5: 613 (2014).

Mottl, M.J. and Wheat, C.G., Hydrothermal circulation through mid-ocean ridge flanks: Fluxes of heat and magnesium. Geochim. Cosmochim. Acta 58, 2225-2237 (1994).

Nakagawa, S. and Takai, K. Deep - sea vent chemoautotrophs: diversity, biochemistry and ecological signiфcance. FEMS Microbiol Ecol, 65, 1-14 (2008) 
Newell, D.L., Crossey, L.J., Karlstrom, K.E., Fischer, T., and Hilton, D.R., Continentalscale links between the mantle and groundwater systems of the western United States: Evidence from travertine springs and regional He isotope data. GSA Today 15, 4-10 (2005).

Northup, D.E., Snider, J.R., Spilde, M.N., Porter, M.L., van de Kamp, J.L., Boston, P.J., Nyberg, A.M., Bargar, J.R. Diversity of rock varnish bacterial communities from Black Canyon, New Mexico. J Geophys Res-Biogeo, 115, G02007 (2010)

O'Nions, R.K., and Oxburgh, E.R. Helium, volatile fluxes and the development of continental crust. Earth \& Planet. Sci. Lett. 90, 331-347 (1988).

Opatkiewicz, A.D., Butterfield, D.A., and Baross, J.A., Individual hydrothermal vents at Axial Seamount harbor district subseafloor microbial communities. FEMS Microbiol Ecol 70, 413-424 (2009).

Porcelli, D., Ballentine, C.J., Wieler, R. Noble gases in geochemistry and cosmochemistry. Rev. Miner. \& Geochem. 47 (2002).

Poreda, R.J., Jenden, P.D., Kaplan, I.R., and Craig, H., Mantle helium in Sacramento basin natural gas. Geochim. Cosmochim. Acta 50, 2847-2853 (1986).

Reid, M.R., Graham, D.W., Resolving lithospheric and sub-lithospheric contributions to helium isotope variations in basalts from the southwestern US. Earth Planet. Sci. Lett. 144, 213 222. (1996).

Reysenbach, A.L. and Shock, E. Merging genomes with geochemistry in geothermal environments. Science. 296, 1077-1082 (2002).

Sano, Y., and Marty, B. Origin of carbon in fumarolic gas from island arcs. Chem. Geol. 119, 265-274 (1995).

Schmandt, B., Dueker, K., Humphreys, E., and Hansen, S., Hot mantle upwelling across the 660 beneath Yellowstone. Earth Plan. Sci Letters 331-332, 224-236 (2012).

Schmandt, B., and Humphreys, E. D. Complex subduction and small-scale convection revealed by body-wave tomography of the western U.S. upper mantle. Earth and Planet. Sci. Lett. 297, 435-445 (2010).

Shen, W., et al., Joint inversion of surface wave dispersion and receiver functions: A Bayesian Monte-Carlo approach, Geophys. J. Int., 192, 807-836, doi:10.1093/gji/ggs050 (2013).

Sherwood Lollar, B., Ballentine, C.J., O'Nions, R.K. The fate of mantle-derived carbon in a continental sedimentary basin: integration of $\mathrm{C} / \mathrm{He}$ relationships and stable isotope signatures. Geochim. Cosmochim. Acta 61, 2295-2308 (1997).

Shock, E.L., et al., Quantifying inorganic sources of geochemical energy in hydrothermal ecosystems, Yellowstone National Park, USA: Geochim et Cosmochim Acta, 74, 4005-4043 (2010). 
Singer E., et al. Mariprofundus ferrooxydans PV-1 the First Genome of a Marine Fe(II) Oxidizing Zetaproteobacterium. PLoS ONE 6:9 (2011).

Suzuki, S., et al. Microbial diversity in The Cedars, an ultrabasic, ultrareducing, and low salinity serpentinizing ecosystem. Proc. Natal. Acad. Sci. 110, 15336-15341 (2013).

Van Horn, D.J., Okie, J.G., Buelow, H.N., Gooseff, M.N., Barret, J.E., and TakacsVesbach, C.D. Soil Microbial Responses to Increased Moisture and Organic Resources along a Salinity Gradient in a Polar Desert. Appl. Environ. Microbiol. 80, 3034-3043 (2014).

Wannamaker, P.E., et al., Lithospheric dismemberment and magmatic processes of the Great Basin-Colorado Plateau transition, Utah, implied from magnetotellurics: Geochem., Geophys., Geosystems, 9, doi: 10.1029/2007GC001886 (2008).

Welhan J.A., Poreda, R.J., Rison, W., and craig, H., Helium isotopes in geothermal and volcanic gases of the western Unityed States, I. Regional variability and magmatic origin. Jour. Volc. \& Geotherm. Res., 34, 185-199, (1988).

Werner, C. and Brantley, S., $\mathrm{CO}_{2}$ emissions from the Yellowstone volcanic system: Geochemistry, Geophysics, Geosystems, 4, (7), doi:10.1029/2002GC000473 (2003).

West, M., et al., Crust and upper mantle shear wave structure of the southwest United States: Implications for rifting and support for high elevation: J. Geophys. Res. 109, (2004).

Whitaker R.J., Grogan D.W., Taylor J.W. Geographic barriers isolate endemic populations of hyperthermophilic archaea. Science 301, 976-978 (2003).

Williams, A.J., Crossey, L.J., Karlstrom, K.E., Newell, D., Person, M., and Woolsey, E. Hydrogeochemistry of the Middle Rio Grande aquifer system - Fluid mixing and salinization of the Rio Grande due to fault inputs. Chem. Geol. 351, 281-298 (2013).

Yuan, H., and Romanowicz, B., Lithospheric layering in the North American craton: Nature, 466, 1063-1069 (2010).

\section{Acknowledgements:}

Funding was from NSF-EAR - 0607808 from the Continental Dynamics Program CREST experiment, NSF EAR-0310323 and EAR-0538304 from the NSF Hydrologic Sciences Program, and NSF EAR-0955909 and EAR- 1356822 from the EarthScope and Geophysics programs. Funding was also from EPSCOR grants 0814449 and 11A-1301346, and the Sloan Foundation (for JWR).

\section{Figure captions}

Figure 1. ${ }^{3} \mathrm{He} /{ }^{4} \mathrm{He}$ values $\left(\mathrm{R} / \mathrm{R}_{\mathrm{A}}\right.$ notation) for hot springs, cool mineral springs, gas fields, and groundwater for the western United States. Helium isotopic values are overlain on P-wave velocity mantle tomography at $80 \mathrm{~km}$ depth (Schmandt and Humphreys, 2010). Blue: interpreted as high velocity, old, and cold lithosphere at $80 \mathrm{~km}$ depths. Yellow to red: lower velocity and 
warmer lithosphere and/or asthenosphere at $80 \mathrm{~km}$ depths, interpreted to be hotter and locally partially molten. Tectonic provinces outlined in black.

Figure 2. Correlation between relative P-wave mantle velocity at $80 \mathrm{~km}$ (Fig. 1) and ${ }^{3} \mathrm{He} /{ }^{4} \mathrm{He}$ ratios $\left(\mathrm{R} / \mathrm{R}_{\mathrm{A}}\right)$ for the different tectonic provinces of western United States. Note log scale for He isotope values. An exponential fit $\left(\mathrm{R}^{2}=0.84\right)$ was applied using the maximum reported ${ }^{3} \mathrm{He} /{ }^{4} \mathrm{He}$ value for each mantle velocity domain $($ Bin size $=1 \%$, minimum number in bin $=10$; see regression methods). Cascadia (blue dots) is not included in the correlation as high velocities reflect the subducting Juan de Fuca slab. He-isotope values that plot well below the trend line are interpreted to represent the dilution/ mixing of mantle-derived fluids carrying high ${ }^{3} \mathrm{He} /{ }^{4} \mathrm{He}$ by the crustal He reservoir. Green points= Yellowstone; Red points= used in regression.

Figure 3. Schematic cross section of the Rio Grande rift showing the conduit system for ascent of mantle volatiles in continental smoker springs. Mantle S-wave data from West et al. (2004).

Figure 4. Taxonomic composition of the major taxonomic groups of bacteria present in four springs at the Tierra Amarilla spring complex. Spring names are given on the left axis (Twin Mound East Spring contained two samples: surface and $2 \mathrm{~m}$ below the surface, 'deep'). Major bacterial taxonomic groups (> $1.0 \%$ of the bacterial community) are listed along the right axis. The columns represent relative abundance of each group within each spring community. The letter after the phylum name precedes the best resolved taxonomic group that the populations can be assigned to (o-order, f-family and g-genus). Results show the dominance of organisms closely related to the chemolithotrophic iron-oxidizing Mariprofundus genus at the Twin Mound East Spring, while Betaproteobacteria closely related to iron-oxidizing, chemolithotrophic Gallionella spp. (further discussed in text) dominate the North Spring bacterial community. Heterotrophic Gammaproteobacteria and photosynthetic Cyanobacteria dominate the other two geographicallyclose springs in the complex (High Spring and Grassy Spring, respectively).

Figure 5. Phylogenetic tree based on the 16S rRNA gene highlighting major bacterial groups (within the Proteobacteria) found at Tierra Amarilla Twin Mound East Spring. Their evolutionary relatedness to chemolithotrophic iron-oxidizing isolates, $M$. ferrooxydans and Sideroxydans spp., which are found in marine and freshwater environments, respectively, are shown. Bolded red lineages were found at Twin Mound East and group with Beta- and Zetaproteobacteria. The 16S rRNA genes from characterized, cultivated isolates are indicated in italics. The 16S rRNA genes from uncultured, environmental Bacteria are indicated by their Genbank accession number, an 'uncultured' label and environment of origin. Two distinct Twin Mound East Zetaproteobacterial groups were present. Group 1 was within a larger Zetaproteobacterial group including uncultured, marine hydrothermal vent Zetaproteobacteria. Group 2was more distantly related to all currently characterized Zetaproteobacteria. The presence of a Betaproteobacterial lineage (TA_deep_165) closely related to the iron-oxidizing, freshwater chemolithotrophic Sideroxydans genus highlights the potential for a diverse, functionally similar chemolithotrophic community present within a single spring. The confidence of 16S rRNA gene placement within this phylogenetic tree analysis (as given by bootstrap percentages of 100 replicate trees) is shown for values $>50$ as black dots (90-100\%) or grey dots (50-90\%). Bacterial groups with more than one representative are collapsed and shown as triangles. The Proteobacteria were rooted phylogenetically with Thermocrinis albus from the 
682 phylum Aquificae. The scale in the lower left shows expected number of substitutions per site as 683 a measure of divergence between lineages.

684

685

686

687

688

689

690

691

692

693

694

695

696

697

698

699

700

701

702

703

704

705

706

707

708

709

710

711

712

713

714

715

716

717

718

719

720

721

722

723

724

725 

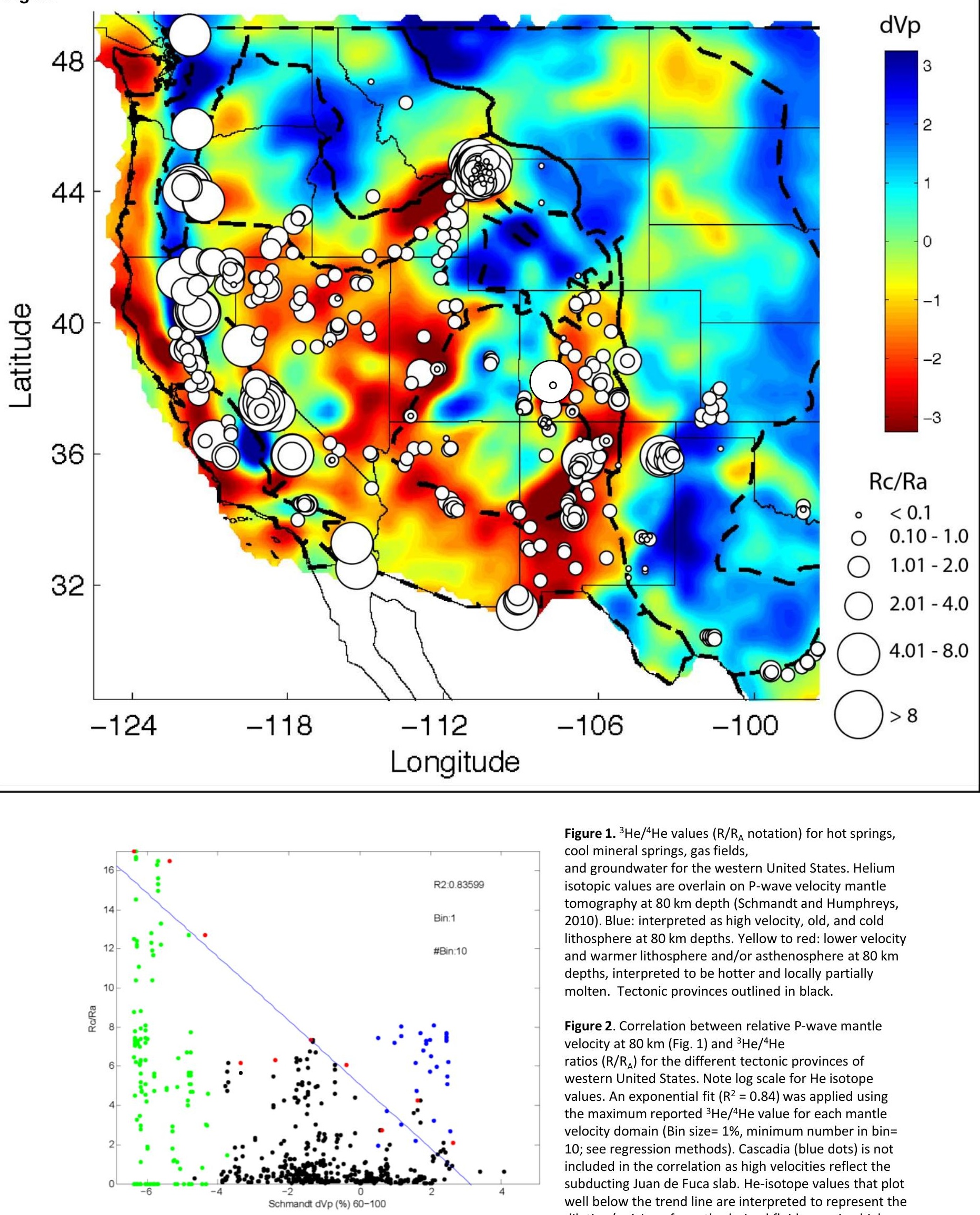

Figure $1 .{ }^{3} \mathrm{He} /{ }^{4} \mathrm{He}$ values $\left(\mathrm{R} / \mathrm{R}_{\mathrm{A}}\right.$ notation) for hot springs, cool mineral springs, gas fields,

and groundwater for the western United States. Helium isotopic values are overlain on P-wave velocity mantle tomography at $80 \mathrm{~km}$ depth (Schmandt and Humphreys, 2010). Blue: interpreted as high velocity, old, and cold lithosphere at $80 \mathrm{~km}$ depths. Yellow to red: lower velocity and warmer lithosphere and/or asthenosphere at $80 \mathrm{~km}$ depths, interpreted to be hotter and locally partially molten. Tectonic provinces outlined in black.

Figure 2. Correlation between relative $\mathrm{P}$-wave mantle velocity at $80 \mathrm{~km}$ (Fig. 1) and ${ }^{3} \mathrm{He} /{ }^{4} \mathrm{He}$ ratios $\left(R / R_{A}\right)$ for the different tectonic provinces of western United States. Note log scale for He isotope values. An exponential fit $\left(R^{2}=0.84\right)$ was applied using the maximum reported ${ }^{3} \mathrm{He} /{ }^{4} \mathrm{He}$ value for each mantle velocity domain (Bin size $=1 \%$, minimum number in bin= 10; see regression methods). Cascadia (blue dots) is not included in the correlation as high velocities reflect the subducting Juan de Fuca slab. He-isotope values that plot well below the trend line are interpreted to represent the dilution/ mixing of mantle-derived fluids carrying high ${ }^{3} \mathrm{He} /{ }^{4} \mathrm{He}$ by the crustal He reservoir. Green points= Yellowstone; Red points= used in regression. 


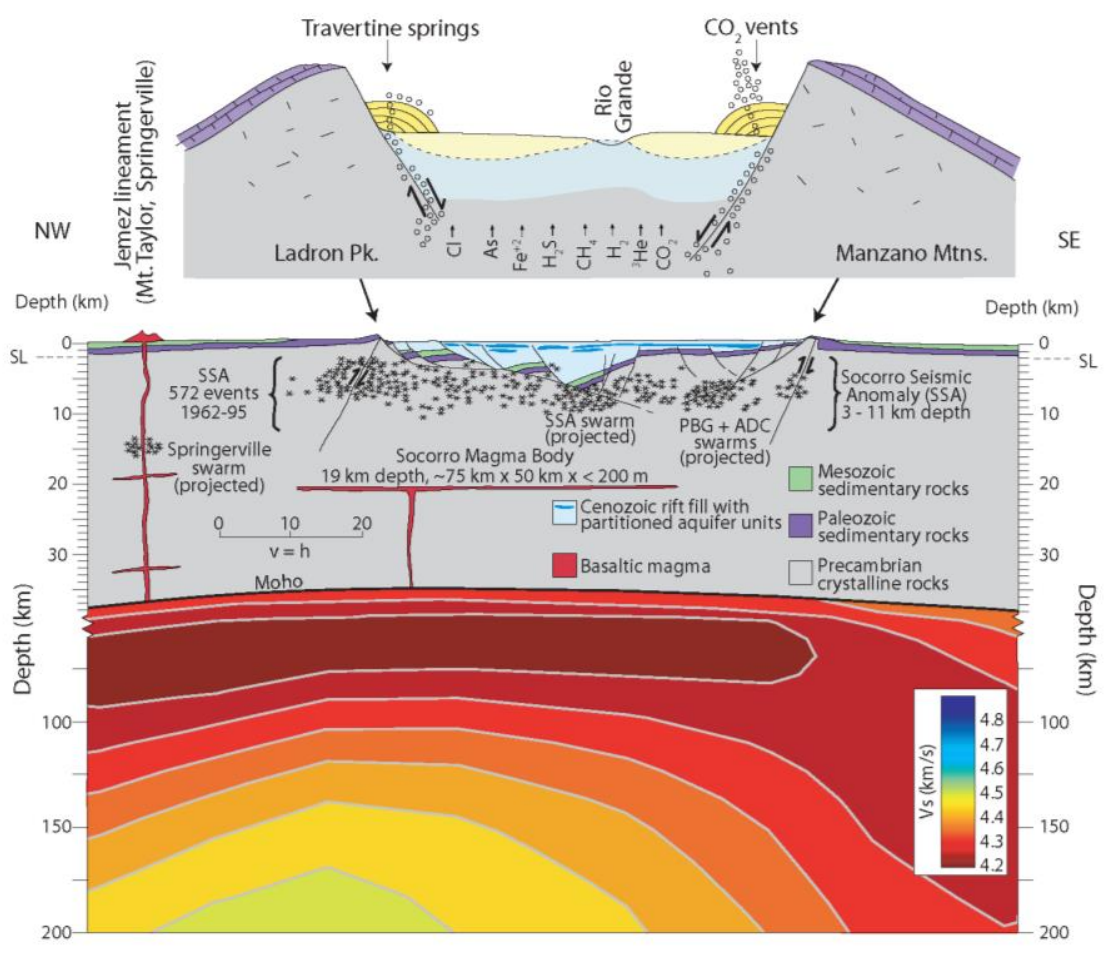

Figure 3. Schematic cross section of the Rio Grande rift showing the conduit system for ascent of mantle volatiles in continental smoker springs. Mantle S-wave data from West et al. (2004). 


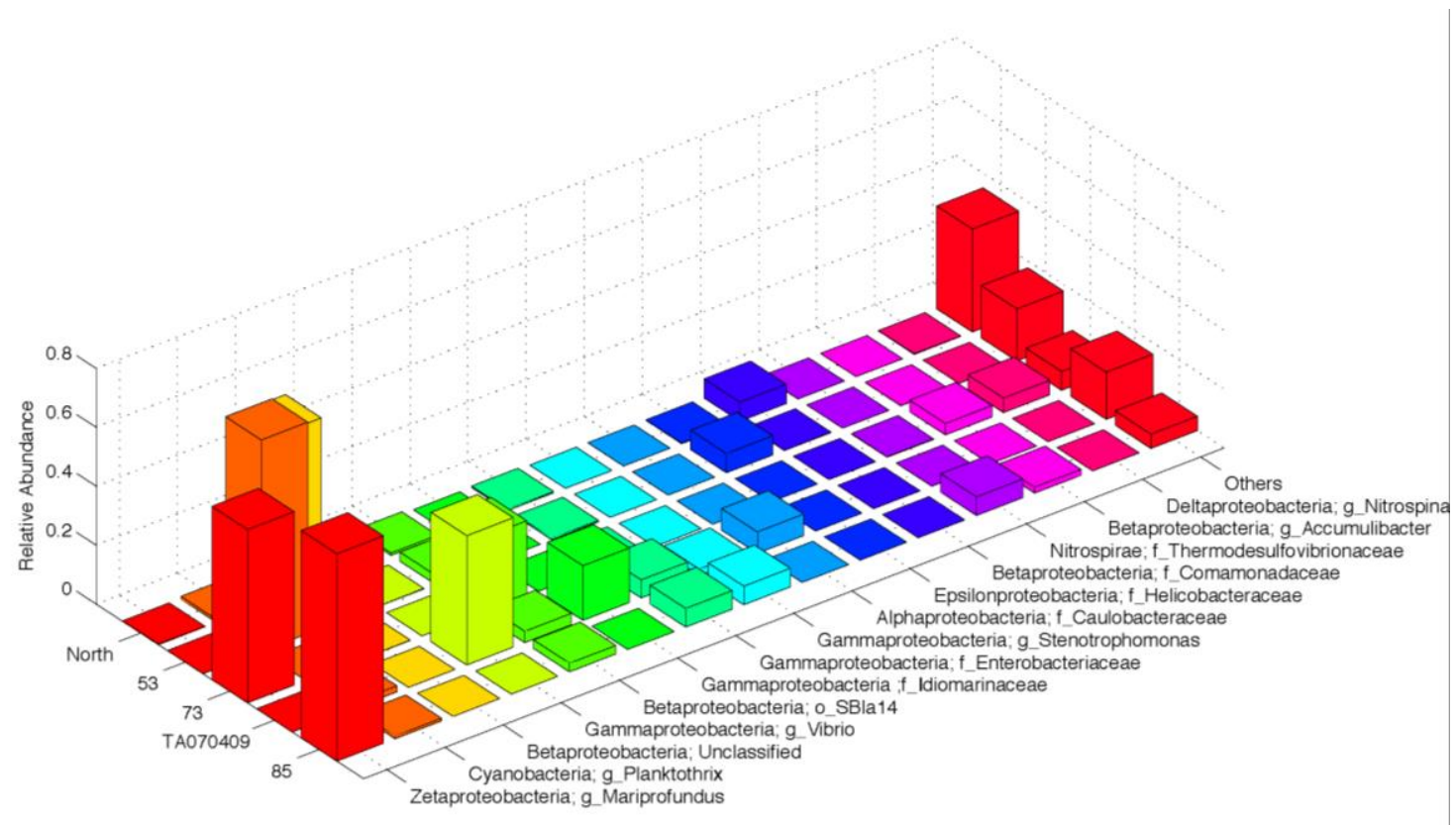

Figure 4. Taxonomic composition of the major taxonomic groups of bacteria present in four springs at the Tierra Amarilla spring complex. Spring names are given on the left axis (Twin Mound East Spring contained two samples: surface and $2 \mathrm{~m}$ below the surface, 'deep'). Major bacterial taxonomic groups ( $>1.0 \%$ of the bacterial community) are listed along the right axis. The columns represent relative abundance of each group within each spring community. The letter after the phylum name precedes the best resolved taxonomic group that the populations can be assigned to (o-order, f-family and g-genus). Results show the dominance of organisms closely related to the chemolithotrophic iron-oxidizing Mariprofundus genus at the Twin Mound East Spring, while Betaproteobacteria closely related to iron-oxidizing, chemolithotrophic Gallionella spp. (further discussed in text) dominate the North Spring bacterial community. Heterotrophic Gammaproteobacteria and photosynthetic Cyanobacteria dominate the other two geographically-close springs in the complex (High Spring and Grassy Spring, respectively). 


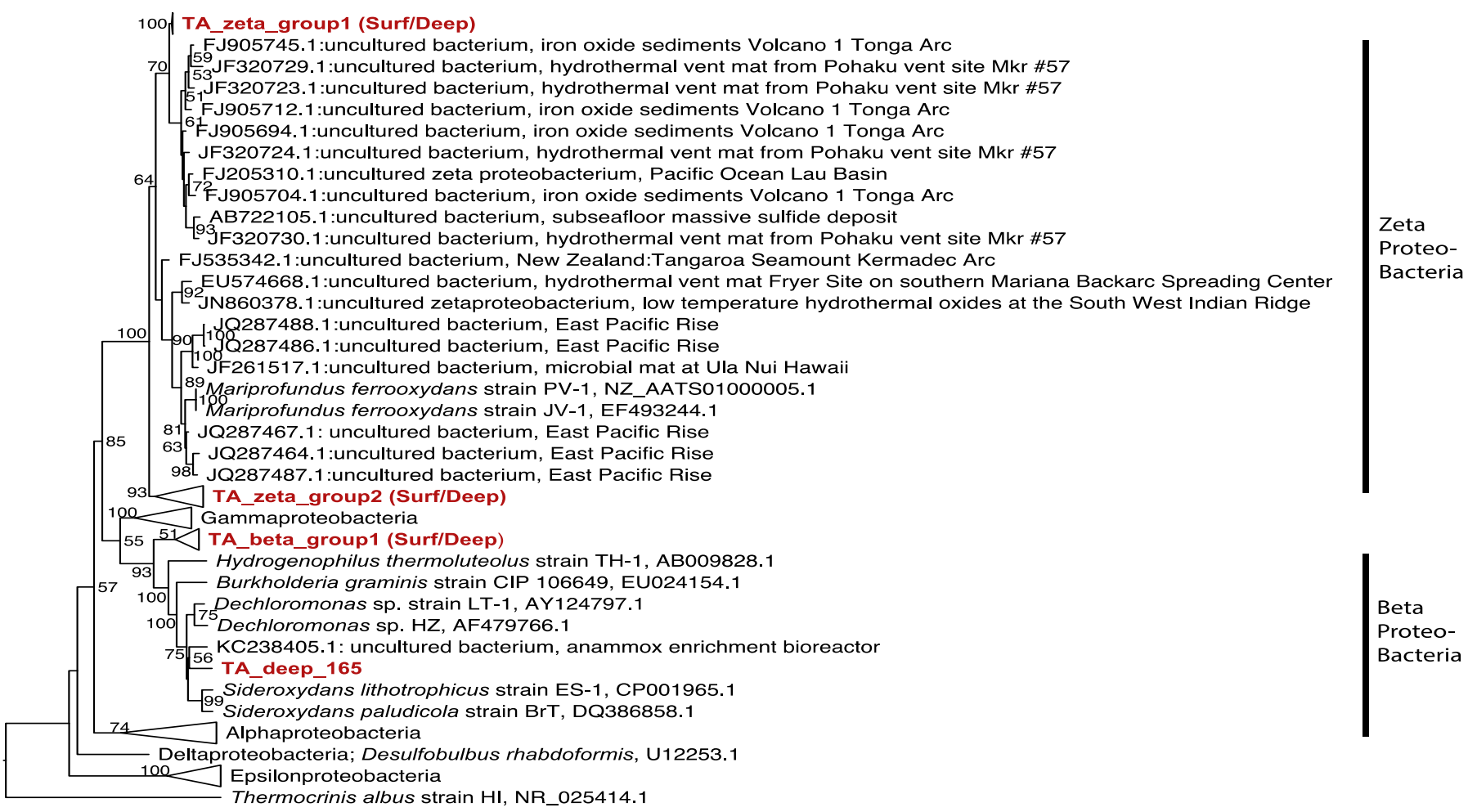

$\overline{0.05}$

Figure 5. Phylogenetic tree based on the $16 \mathrm{~S}$ rRNA gene highlighting major bacterial groups (within the Proteobacteria) found at Tierra Amarilla Twin Mound East Spring. Their evolutionary relatedness to chemolithotrophic iron-oxidizing isolates, M. ferrooxydans and Sideroxydans spp., which are found in marine and freshwater environments, respectively, are shown. Bolded red lineages were found at Twin Mound East and group with Beta- and Zeta-proteobacteria. The 16S rRNA genes from characterized, cultivated isolates are indicated in italics. The 16S rRNA genes from uncultured, environmental Bacteria are indicated by their Genbank accession number, an 'uncultured' label and environment of origin. Two distinct Twin Mound East Zetaproteobacterial groups were present. Group 1 was within a larger Zetaproteobacterial group including uncultured, marine hydrothermal vent Zetaproteobacteria. Group 2 was more distantly related to all currently characterized Zetaproteobacteria. The presence of a Betaproteobacterial lineage (TA_deep_165) closely related to the iron-oxidizing, freshwater chemolithotrophic Sideroxydans genus highlights the potential for a diverse, functionally similar chemolithotrophic community present within a single spring. The confidence of $16 \mathrm{~S}$ rRNA gene placement within this phylogenetic tree analysis (as given by bootstrap percentages of 100 replicate trees) is shown for values $>50$ as black dots $(90-100 \%)$ or grey dots (50-90\%). Bacterial groups with more than one representative are collapsed and shown as triangles. The Proteobacteria were rooted phylogenetically with Thermocrinis albus from the phylum Aquificae. The scale in the lower left shows expected number of substitutions per site as a measure of divergence between lineages. 